\title{
The rôle of knowledge in system risk identification and assessment: the 2014 Ebola outbreak
}

${ }^{1}$ Professor JH Powell (corresponding author), Chair of Strategy, University of Exeter Business School, Streatham Court, Rennes Drive, Exeter, UK ,EX4 4ST

email: j.h.powell@exeter.ac.uk

${ }^{2}$ Dr Navronil Mustafee, Senior Lecturer, University of Exeter Business School

email: N.Mustafee@exeter.ac.uk

${ }^{3}$ Dr Colin S Brown, Infectious Diseases Advisor, King's Sierra Leone Partnership, King's Centre for Global Health; Locum Consultant in Infectious Diseases \& Medical Microbiology, National Infection Service, Public Health England; Honorary

Consultant in Infectious Diseases \& Medical Microbiology, Department of Infection, Royal Free NHS Foundation Trust

Email: colinbrown@ doctors.net.uk

\begin{abstract}
Current approaches to risk management stress the need for dynamic (i.e. continuous, ongoing) approaches to risk identification as part of a planned resource application aimed at reducing the expected consequences of undesired outcomes for the object of the assessment. We contend that these approaches place insufficient emphasis on the system knowledge available to the assessor, particularly in respect of three related factors, namely the dynamic behaviour of the system under threat, the role of human agents and the knowledge availability to those agents.

In this paper, we address the rôle of knowledge use and availability in critical human activity systems (CHASs). We emphasize the distinction between information used within these systems as distinct from the knowledge deployed by their human inhabitants.

The aim of the paper is to offer a procedure for the mobilization of knowledge assets in the identification and management of risk within the system, building upon previous work which focused on the mobilization of knowledge about the system. We see knowledge as being a system asset, both deployed within and originating from system behaviour.
\end{abstract}

Using the ongoing 2014-2015 West African Ebola outbreak as an example, we offer a practical procedure using the well-known systems dynamics technique in its qualitative form (QSD) for the identification of risks and appropriate policies for managing those risks. 


\section{The rôle of knowledge in system risk identification and assessment: the 2014 Ebola outbreak}

\section{Introduction}

This is one of a short series of papers (Powell et al, 2016; 2017) concerned with the identification and assessment of system risk as part of overall risk management, the process of identifying appropriate policies for the control and mitigation of risks under inevitably limited resource availability. Our focus is on safety and mission critical systems, particularly those which contain human agents whose decisions and actions form an inextricable part of the system assets.

Checkland refers to these latter as human activity systems or HASs (Checkland and Scholes, 1990) and by extension we refer to the safety and critical subset of these as critical human activity systems, henceforth CHASs. We adopt a systemic approach in continuation of the line of system-focused OR work advocated by Ackermann and others over some years (Ackermann et al, 2007, 2014).

An earlier paper (Powell et al, 2016) concentrated on system-based approaches to risk management. Such approaches can be seen through a knowledge lens in the sense that knowledge of the dynamics of a system is relevant in in understanding the origins of its risks. However, such knowledge is about the system, rather than being part of and therefore within the system. We distinguish therefore between 'etic' knowledge (i.e. knowledge about the system) and 'emic knowledge', being knowledge which forms part of the system itself.

We also recognise the distinction between information and knowledge used within the system, whether by human agents or by automatic procedure.

Our perspective on the roles of the human agents, the knowledge which they use and the physical system which both inhabit (known as the infrasystem for convenience) is that these are inextricably connected - neither has a system existence separate from the other. While it may from time to time be useful to focus upon the knowledge, the human agents or the infra-system, in fact they are projections of a single system definition, which is that of an infrasystem inhabited by human agents who utilize, process and indeed co-produce knowledge as part of that system's operation.

The human agent, in interacting with the system of which he or she is a part, utilizes many resources, depending on the task and role, but, in one form or another, knowledge is always part of that applied resource set, even if it is only knowledge of the individual's role in the system. On a philosophical basis one could attempt to construct an artificial circumstance in which a human agent is an unknowing part of the system, say as a collateral victim of a disaster but in that extreme case we argue that the human agent then falls outwith the system boundary.

\section{The context of risk identification and assessment}

\section{Risk management}

Risk identification, a precursor to the assessment of risk, is a subset of risk management, which, in general usage (AIRMIC/ALARM, 2010; Crockford, 1986; Hopkin, 2012; USEPA, 2004) refers to a process of identification and assessment of 
the likelihood of occurrence and impact of deleterious outcomes of an object in focus resulting from (potential) risk events which may or may not be reified in a particular circumstance (ISO/IEC, 2009; Stoneburner, Goguen and Feringa, 2002). We shall refer to the object of this analysis as a system (NIOSH, 1998), since, for it to be worthy of consideration, it will be of a complexity and span of impact greater than a single, undifferentiated event. In the case of an outbreak of an infectious disease, for example, the system is the logistic, clinical, social, economic, and political context in which an 'infective event' takes place.

Risk management as a process, then, moves from identification and assessment to control, mitigation and consequence management (Moteff, 2005), seeking to accommodate inevitable resource limitations within an action plan (ISO/DIS 31000, 2009) aimed at satisfying a set of outputs or consequences of the causative risk event (Stoneburner, Goguen and Feringa, 2002). It is the identification phase with which we are concerned here.

\section{Overall process of risk identification}

We note several general shortcomings in the accepted general practice of risk identification and its relations to system knowledge.

The increasingly popular taxonomic and objective-based risk assessment (Trickey, 2011; Airmic / Alarm / IRM, 2010; Borodzicz, 2005; Dorfman, 2007) are relevant, but while such approaches implicate the internal behavioural characteristics of the object under assessment (what we will refer to as the system behaviour), there is limited evidence of this important source of system risk knowledge being mobilized in an explicit way. Where there is evidence of knowledge being deployed it appears to be seen exclusively as an 'emic' property (de Zoysa, 2003; Ruzic-Dimitrijevic, 2014). There is thus a tendency both in academic literature and in practice to interpret the term 'dynamic' [as in 'dynamic risk assessment"] as being to do with the extent to which the risk assessment is performed on a continuing basis, as opposed to a oncefor-all snapshot (Adams, 1995; Nederpelt, 2012).

Second, although in a significant class of systems (safety or mission critical systems) the rôle of humans is frequently critical, we observe little in the way of structured analysis of the rôle of human agents in the operation of the assessed system (Hopkin, 2012). We refer to these, pace Checkland (Checkland and Scholes, 1990) as critical human activity systems or CHASs.

Third, particularly in the case of CHASs, there is little analysis of the rôle of knowledge in the interaction of the human agents with the system under assessment (Hillson and Murray-Webster, 2007). It is clear that, in a substantial sub-class of CHASs, the use of knowledge (as distinct from, but supported by information and its processing) is of critical importance in achieving the desired system behaviours.

Mutatis mutandis, failure to provide relevant knowledge at the point and time of need can, in itself, provoke or even constitute system failure (Hubbard, 2009). The knowledge in a system is as much a part of that system as the system itself and its users carry, derive, import, disseminate and use that knowledge as part of that system. Thus, the rôle of knowledge not only influences the system behaviour and hence its outputs at a particular time, but, through the co-production, importation and publishing processes, determines not only the behaviour of a system at a future time, but even the definition of the system itself, on the argument that the knowledge within the system forms part of the system itself. 
Fourth, it is not clear from the existing literature whether sufficient emphasis is given in risk identification and assessment to the plural nature of the valuation of risk outcomes, by which we mean the different valuations placed by different stakeholders on system outcomes (Checkland and Scholes, 1990; Clarke, 2001). This also forms the subject of future work.

The aim of this paper is to demonstrate a workable practical procedure for the inclusion of knowledge considerations in the risk identification process (critique 3 above). We build on the knowledge management literature where system modelling methods have been used to map knowledge deployed in an organisation in order to manage that knowledge better. Here, however our managerial intent is different, namely to identify the rôle of knowledge in the system processes in order to determine where risks may emerge, primarily from the absence of knowledge (both tacit and explicit) at the time and place of need in the decision processes constitutive of the CHAS.

\section{Knowledge and Risk Analysis}

\section{Existing approaches}

At first glance interest in the knowledge dimension of risk in systems appears extensive; a simple search on Scopus of key terms "Risk analysis AND knowledge" results in some 46,800 results. Analysis of the scope and assumptions of these papers shows patterns, however, which indicate some gaps in the treatment of knowledge as a system component in and of itself.

Knowledge risk (Ishikawa and Naka, 2003; Massingham, 2010) is an analytical objective in many application domains such as IT (Varajao, et al, 2017), disaster risk management (UNISDR, 2014, 2105a,b; Spiekermann et al, 2015), fisheries (McDonald et al, 2017), supply chains (Raut et al, 2017), social risk, ecological (Asfaq, 2017; Lou et al, 2017), safety at sea (Goerlandt et al, 2017), safety critical systems (Scott-Parker and Oviedo-Trespalacios, 2017; Bachani et al, 2017) and indeed in the effectiveness assessment of Knowledge Management itself (Boy and Barna, 2005; Benoit, 2011; Ruzic-Dimitrijevic, 2014).

We observe in this extensive literature a clear tendency to treat knowledge as an aggregated, property of the system-in-focus (etic knowledge). No publications treat the knowledge within the system (emic knowledge) and, particularly the intimate connection between this within-system knowledge, the human agents and the underlying infrasystem, although there is some evidence of awareness of the need for this specificity in medical and social risk studies (Ashfaq et al 2017; Lou et al, 2017, Busby et al, 2017).

In many cases, what is considered as specific knowledge in a system (such as the awareness of speed limits in road safety (Bachani et al, 2013) or the correct weighting of personal risks in a nuclear accident (Busby et al, 2017)) would be characterised as information, often critically important in its effect, but failing to satisfy ubiquitous criteria such as justified true belief, or more sophisticated understandings of knowledge. This latter view of knowledge can be seen essentially as a superior, contextualised or aggregated property of information (Davenport and Prusak, 1998) and/or as a social property deriving from the interaction/connectedness between persons (Berger and Luckmann, 1966; Polanyi, 1966; Tsoukas and Vladimirou, 
2001). Critically, knowledge is seen as a distributed property of an organisational system (Tsoukas, 1996; Scarbrough et al., 1999; Powell and Swart, 2010) and, moreover, one which possess the capacity for action by an agent, an idea encapsulated in the acronym KHIA, or knowhow in action (Swart, 2011). There is, additionally, little evidence in these risk assessment approaches of the important distinction between explicit and tacit knowledge (Polanyi, 1966; Davenport and Prusak,1998; Baumard, 1999; Tsoukas and Vladimirou, 2001).

\section{emic and etic knowledge}

This apparent neglect of the importance of knowledge (as distinct from information) in these systems is exacerbated by the failure to distinguish between knowledge about the system (etic knowledge) and that which forms part of the system itself (emic knowledge). There is some literature which discusses etic knowledge. Benoit, (2011), for example, discusses the most common failures of Knowledge Management systems; Apgar (2006) sees risk as 'a learnable event'; Verhagen (2005) discusses how 'knowledge informs decision makers'. Each of these authorities (which are together representative of the entirety of the literature) are concerned with knowledge of the system (etic) as opposed to that which is used as part of the system in operation. To decode: the reader may have knowledge about neurosurgery; the surgeon has knowledge of it, which he uses in carrying out the procedures in the operating theatre. It makes little sense to see as separate the surgeon and what he knows in effecting system output.

\section{KM approach}

There is evidence in the literature of the application of Knowledge Management (KM) approaches to the analysis of risk (Massingham, 2010; Boy et al, 2005, for example). Again, these approaches concentrate on the etic form of knowledge, producing managerial advice on knowledge risk reduction emerging from KM such as: establishing a learning climate; mitigating knowledge loss; creating channels for knowledge flow; developing a team shared memory and using the risk register to monitor knowledge risks. While these are clearly beneficial, they retain the disadvantage that they are dealing with knowledge in the system-in-focus as if it were separated from it rather as an emic component of the system, associated with but different from, say, the human agents who form part of the system.

\section{Types of risk}

Existing literature does provide a useful taxonomy of knowledge risk.

- Absence

- Incorrect knowledge (often called negative knowledge)

- Insufficient

- Selection risk (identifying the wrong knowledge to an application) (Ishikawa and Naka, 2003)

- evaporation risk (knowledge becoming irrelevant over time)

- Improper use 
- Problems of knowledge sharing

(Riege, 2005)

- Causal and resultant risk in KM

(Frost 2014)

But again, examination of these categories indicates an acceptance of the rôle of knowledge as an etic property rather than as an inherent, emic, system property and component.

It is this latter stance which we adopt in this paper.

\section{Utility}

In addition to the general benefits accruing from a system-informed risk assessment process (Ackermann, 2007, 2014; Powell et al, 2016) we note the observations of Aven $(2013,2016)$ on the need for integrative approaches and 'broader perspectives on the conceptualisation, assessment and management of risk", with particular emphasis on "knowledge and lack of knowledge descriptions and characterisations in risk assessments". Our intention in this appear is to move towards the fulfilment of that need for the specific inclusion of emic system knowledge in risk identification, as a part of the risk assessment process.

\section{Risk identification process advocated}

The risk identification process described in this paper entails a dynamic analysis of a qualitative system dynamics model (Coyle, 1996; Eden, 1989) having the general architecture of Figure 3. It builds on the basic process described in a previous paper (Powell et al, 2016), adding additional steps aimed at identifying the knowledge deployed by human agents (individually or in groups) in enacting the dynamic processes (Powell and Swart, 2005). In summary, the procedure is as follows:
a. Construction of a System Dynamics Influence Diagram (ID) covering the required span of managerial interest.
b. Examination of the key dynamic processes in the ID, represented by the loops.
c. Identification of the human agents enabling those processes.
d. Identification of the knowledge deployed in those processes by the human agents
e. Identification of those knowledge components which have the capacity, if absent at place and time of need, to act as disruptors of the system performance.
f. Identification of the effects of such disruptions.
g. Expression of the risks identified thereby.

Clearly subsequent risk analysis can identify mitigation, effects analysis and residual risk appraisal in the manner of existing practice.

\section{Ebola outbreaks}

Ebola, or more correctly, Ebola Virus Disease (EVD), is a highly infectious disease with a history of explosive occurrence in sub-Saharan Africa. There have been 
outbreaks since its discovery in 1976 in The Democratic Republic of Congo (Anon, 2003; Chowell et al, 2004; Dowell et al, 1999; Kerstiens and Matthys, 1999; Khan et al, 1999; Muyembe-Tamfumm et al, 1999), Zaire (Anon, 1978b; Breman et al, 1978; Team RoaWIS, 1978; Walsh, 2005), Northern Uganda (Anon, 2001; Borchert et al, 2011; CDC, 2001; Francesconi et al, 2003; Hewlett and Amola, 2003; Raabe et al, 2010), Gabon (Georges et al, 1999), Sudan (Anon 1978a; Baron et al, 1983)), and, recently in a group of countries in West Africa, this latest outbreak being the largest in recorded history by some significant margin (See Figure 1) (Dixon and Schafer, 2014; Merler et al, 2015; Nishiura and Chowell, 2014; WHO Ebola Response Team, 2014; Yamin et al, 2015). The first case occurred in Guinea in December 2013, and the outbreak was recognized in March 2014 whereafter it quickly spread to Liberia (New York Times, 2014), Sierra Leone by May and reached Nigeria in July 2014 and Mali in October 2014. By August 2014, the World Health Organization had declared the outbreak a Public Health emergency of International Concern (PHEIC), and by September 2014 several cases had been reported outside Africa deriving both from infected health workers and from returning ex-patriate citizens, including the United Kingdom (UK). There was limited spread of the disease to carers in both the United States and Spain, curtailed by in situ procedures and processes in these more developed countries (WHO, 2016).

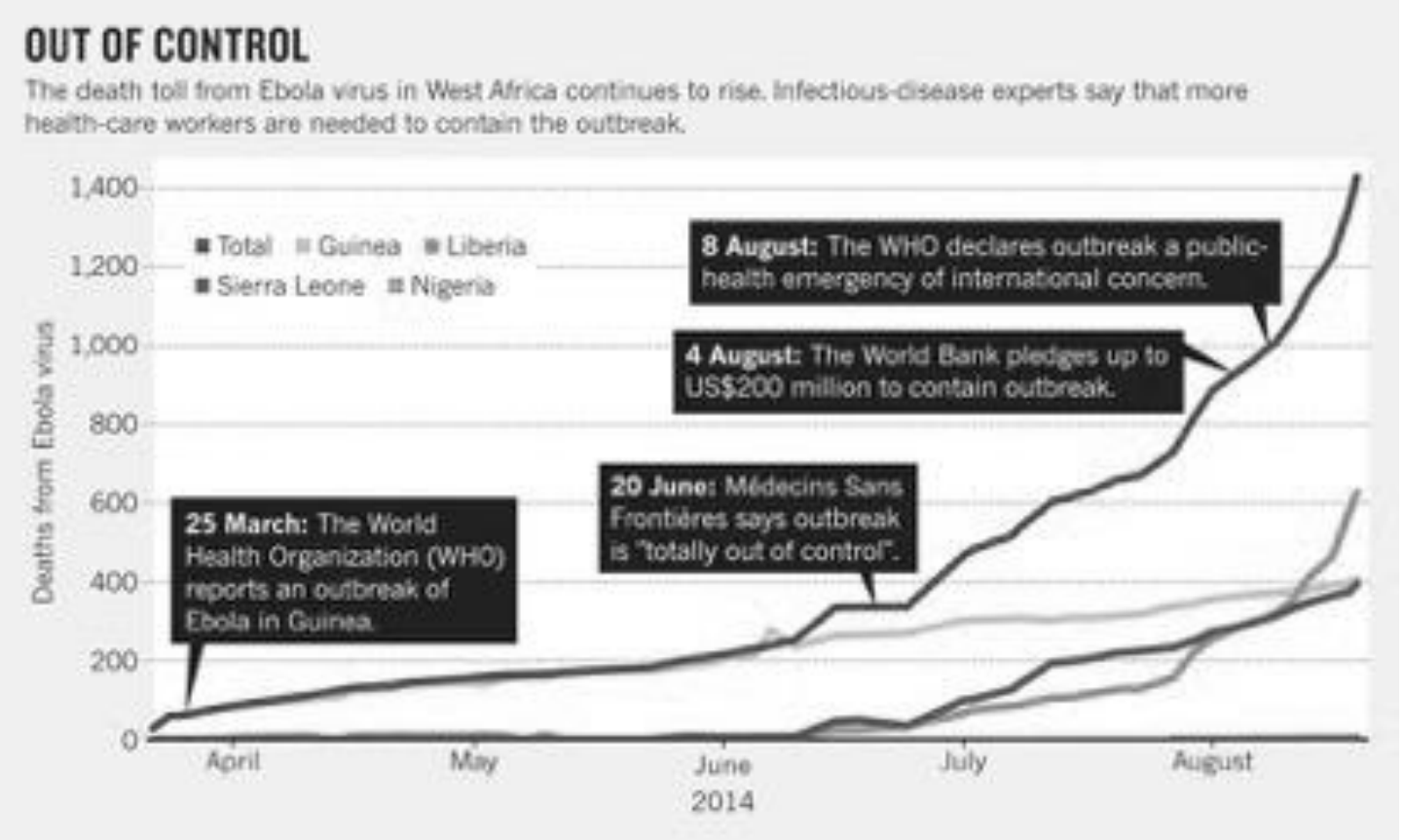

Figure 1: Explosive growth of EHF in West Africa 2014 (from E Check Hayden, 2014) 


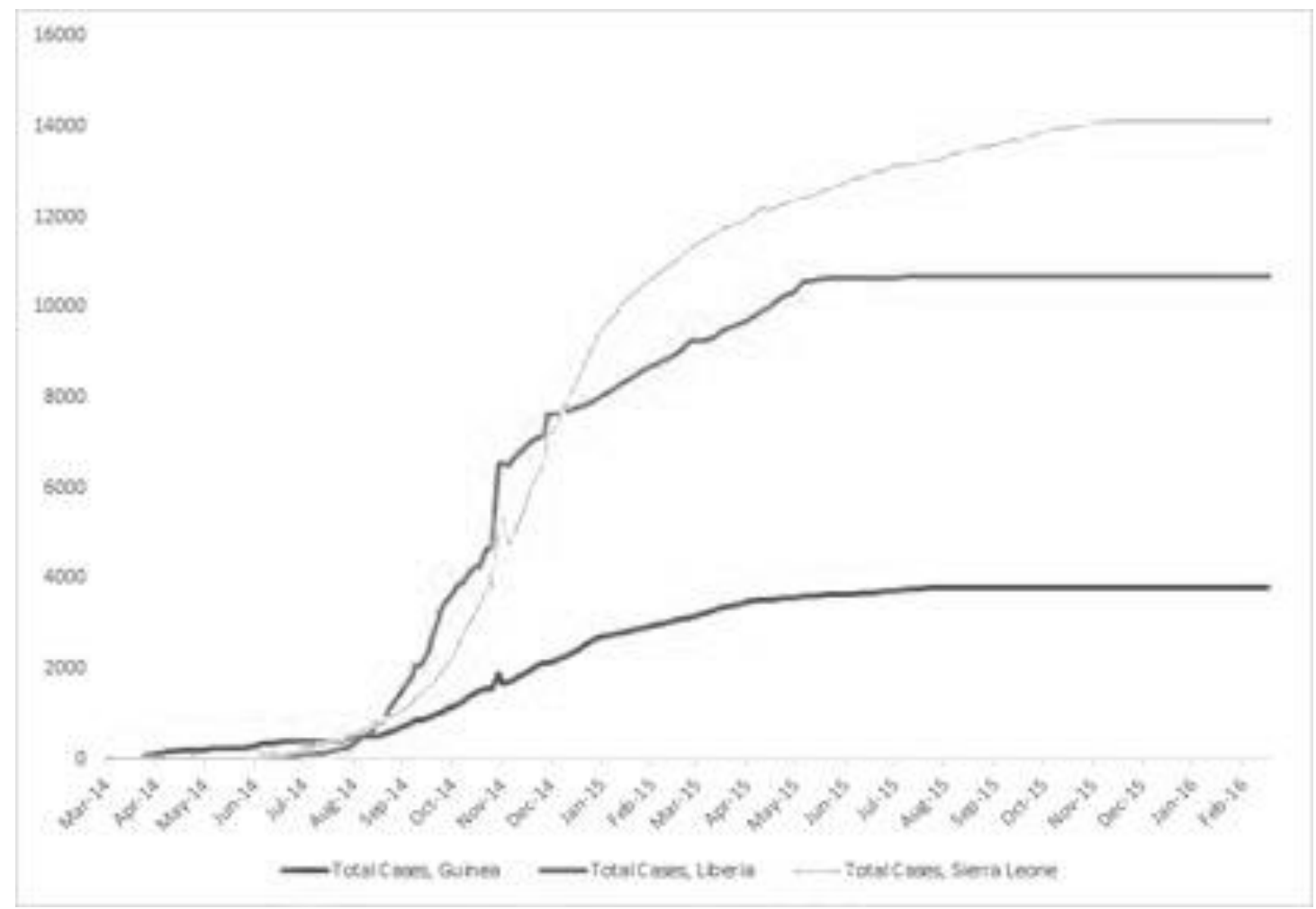

Figure 2: Weekly reported cases in three countries 2014 to 2016 (CDC, 2014)

At the close of the outbreak, with the PHEIC declared over on $29^{\text {th }}$ March 2016 and Liberia declared Ebola free on $9^{\text {th }}$ June 2016, there had been 28,616 reported cases with 11,310 deaths, over ten times more cases than the sum total of all previous outbreaks (WHO, 2016b; CDC, 2017). 27 patients were manged in Western countries, with a grossly different case fatality rate than those seen in West Africa, of $18.5 \%$, likely reflecting the vastly different resources in caring for these patients in more resource rich settings Uyeki et al, 2016).

Though many novel therapeutic interventional agents were trialled, none showed any conclusive survival benefit. The one success of the response was the rapid deployment of a vaccine trial, which even though it was present at the end of the epidemic through an adaptive design demonstrated that 'ring-fence' vaccination of household contacts of a newly diagnosed case afforded considerable protection directly to the individuals and the wider community (Brown et al, 2017). This will be of considerable importance in future risk assessment.

Novel surveillance activities in Sierra Leone included 'lockdown' activities with a door-to-door initiative searching for Ebola cases, centralised command and control structures, and community event based surveillance through training community members in rapid case detection and reporting (Houlihan et al, 2017).

Considerable import has been placed on learning lessons from such as unprecedented outbreak, including the need for harmonised donor approaches to funding and support (STC, 2016) appropriate in situ plans for the delivery of a combined scientific and public health response such as the development of the UK Rapid Support Team 
(Reece et al, 2017), and a more inclusive early approach to community engagement as a 'critical operational tool' (Gillespie et al, 2016).

Previous EVD outbreaks have mostly occurred in rural villages with limited infrastructure, resulting in outbreaks with high case fatality rates (because of limited diagnostics and treatment measures and lack of expertise in managing viral haemorrhagic fevers) but limited transmission (because of the communicative isolation). With the spread of infection to cities in all three main countries affected in the 2014-2016 outbreak, however, a wider set of factors came into play (Check Hayden, 2014). Not only was there increased travel from isolated areas to the infection centres, but industrialization and commerce in the urban infected areas provided mechanisms for contact between infectious individuals and those as yet unaffected. Counter-intuitively, there is also some evidence that access to the very health facilities aimed at suppressing the outbreak, in fact provide infection contexts, particularly early in the outbreak if adequate infection control measures are not adhered to. There was also early mistrust of the practices of care inside Ebola Treatment Centres, carried out away from public scrutiny inside isolated facilities by masked healthcare providers. This was later changed to allow communities more direct access to care, such as through removal of high perimeter fences (MSF, 2015)

Cultural practices contributed to the extent of the outbreak, since there is a high risk for infection through contact with infectious body fluids, particularly during traditional burial practices (Folashade et al, 2015). There were reports of beliefs early in the outbreak that EVD was an attempt by authorities to suppress local populations and that the health facilities themselves were the source of infection. This can result in cases being hidden from regional authorities, again prominent early in the disease transmission (Cafod, 2015).

The effects of Ebola are not limited to health issues, however. "The consequences of Ebola are vast," said Abdoulaye Mar Dieye, the Director of UNDP's Regional Bureau for Africa. "Stigma, risk aversion and shutting down of borders have caused considerable amounts of damage, affecting economies and communities in a large number of countries across the sub-region" (UNDP, 2015). International trade issues are also relevant, with inevitable, though somewhat overblown concerns in developed countries over the dangers of infection through international travel (Gomes et al, 2014). It is estimated (CDC, 2016) that the West African Outbreak resulted in a $\$ 2.2$ billion loss in gross domestic product for Sierra Leone, Guinea and Liberia.

We thus see that EVD possesses a number of characteristics which make it suitable as a study for the rôle of knowledge in critical human activity systems.

- It is a significant human problem for a number of interested parties or stakeholders, which include patients, health workers, citizens of West African and other countries, travellers, governments, police authorities and aid agencies.

- It is sufficiently complex, both in the sense that it is not well understood and because it is multifaceted, having, even at the highest level, aetiological, economic and political components. It is also likely to include non-linearities both in its component linkages and in its inputs over time (for example the arrival of RFA Argus, bearing 700 UK health workers, to Freetown in October 2014).

- Knowledge, both tacit and explicit, bears strongly on the performance of at least one component of the problem, namely the treatment of infected persons. 
- The rôle of risk identification is clearly important in the future management of similar epidemic crises in order to limit direct and indirect effects and in the optimization of resource provision both in quantity and time.

\section{Knowledge considerations of Ebola}

The extent of the Ebola 'system', by which we mean the set of interconnections which together create the outputs valued by and affecting stakeholders, is rather wide. It has immediate and local effect in the societies directly affected by the outbreak, effects which can be directly observed, measured and explained in a scientific manner, relying on empirical, testable data (the physical sub-model). It also has effects deriving from socially-constructed phenomena, such as confidence in the economy, fear in the population, and distrust in control measures (the social context sub-model). Lastly, it has a political component, in the strict sense of considerations of policy, primarily resource allocation decisions reacting to observed system effects, the results of which affect not only the region but also the wider world (political and policy submodel). These are interconnected. See Figure 3 (Powell et al. 2016).

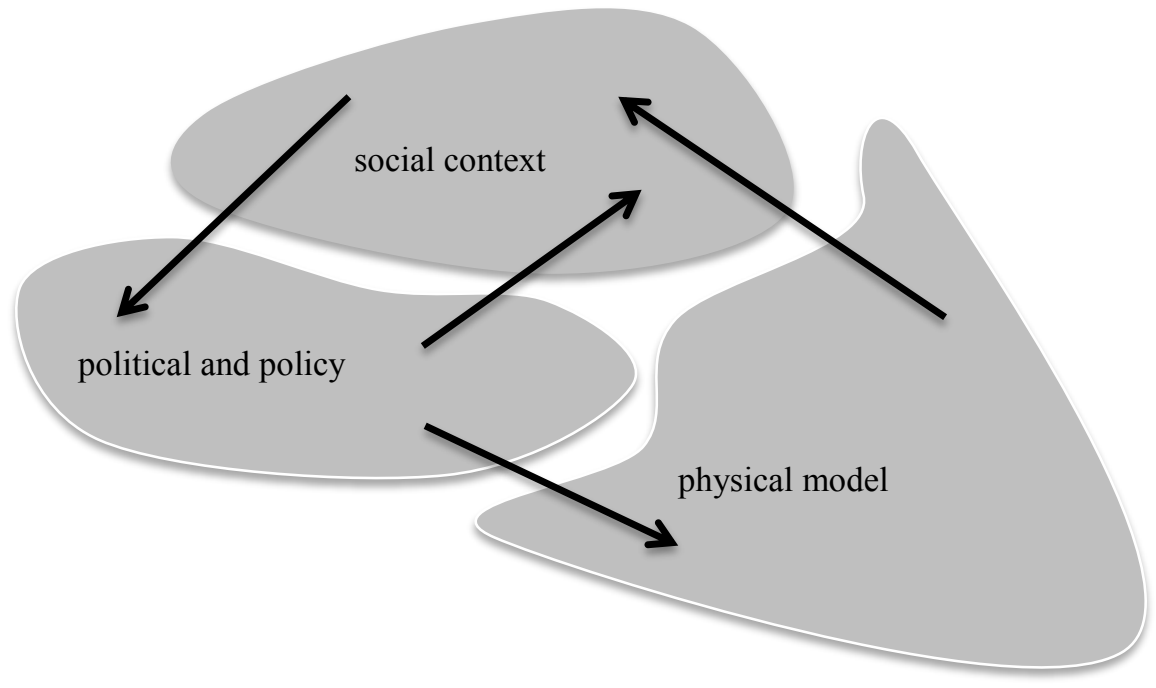

Figure 3: Interconnection of sub-models (from Powell, et al, 2016)

The next section will discuss the content of the model which we use later to investigate the risks present in the EVD outbreak, taking a knowledge perspective which is an extension of the general system dynamic treatment described elsewhere (Powell and Coyle, 2005; Powell and Swart, 2010; Powell et al , 2016). For the moment, we restrict ourselves to a brief listing of the main knowledge issues emergent ex ante from the extensive literature on EVD outbreaks. These can be divided into obvious groupings consonant with the architecture of Fig 3.

Physical context

- Knowledge and skills of health workers, their despatchers and resource analysts are clearly a significant component of the disaster control processes. Recognition of the need for future resourcing in particular is of specific concern in an accelerating outbreak, alongside appropriate actions at each stage of disease progression including recognition of bottlenecks in diagnosis, isolation, identification of patients, their subsequent treatment, and safe burials where necessary. 
- Knowledge of the aetiology of the virus, and consequent epidemic dynamics, as well as specifics of local high-transmission risk activities.

- Equally, knowledge of the occurrence and distribution of infection in the populace, including air travellers (Bogoch et al, 2105), allows prompt identification and hospitalization of patients (Borchert et al, 2011; Farrar and Piot, 2014) an important factor in preventing the spread in urban areas, in particular (Kerstiens and Matthy, 1999; Ndambi et al, 1999).

- Knowledge of infection mechanisms on the part of the population at risk informed by socially constructed beliefs (see below) conditions behaviour in the vicinity of potentially affected persons (Rowe et al, 1999). As an example, "After a villager there tested positive for Ebola, police put two houses under quarantine - and six people fled. Barrie, along with community leaders and public-health workers, then visited the remaining 30 residents to explain the reason for the quarantine and to answer questions. One man said that he needed someone to go and buy cigarettes, and another needed palm wine; health officials tasked a worker with making these daily deliveries. (Check Hayden, 2014).

Social context

- Assumptions and beliefs about the nature and origin of Ebola: its attribution to natural causes vis-à-vis 'political intervention', the benefits of community interventions such as quarantine and restrictions on physical movement, and the likelihood that presenting for care would affect outcomes (Check Hayden, 2014).

- Enculturated knowledge/belief about appropriate burial and associated practices (Raabe et al, 2010); Dowell et al, 1999).

- Understanding the role of ethnic, cultural and national identities in an affected region involving communities that span shared borders.

- Extent of understanding in the developed world about the need for intervention, particularly with regards to scale and rapidity of action.

- Perceptions in the developed world about the risks associated with air travel from the region.

Political and policy context

- Acceptance and commitment of regional and developed-world authorities to intervention leading to direct and indirect foreign aid.

- Perception of political threat to developed world and regional polities.

There exists a clear difference in the outbreak curves seen in Figure 2 in the most affected countries, which has implications for the past and future control efforts. Those seen in Liberia and Sierra Leone both represent standard outbreak curves i.e. there is an incremental start, an exponential increase in cases as the infection spreads rapidly through a susceptible population, followed by a tail that represents the effects of either outbreak control measures (as in this case) or diminishing numbers of susceptible individuals, the rest having either survived with immunity or died. The curve for Guinea is different, and at first glance may suggest that there have been better control efforts there than the other countries. However, the propagated nature suggests ongoing exposure, and indeed much later in the epidemic, at the tail of the 
other countries, there remained a higher and static number of new infections. In addition, in Sierra Leone and Liberia most new cases arose from known contacts in quarantine, whereas in Guinea many cases could not identify an obvious contact. The implications of this include the possibility that there is circulating and potentially unreported cases in the community, with ongoing transmission outside of known networks. This small but steady number of new cases is therefore of significant concern.

We now proceed to describe the extensive model on which the risk identification process is carried out.

\section{General modeling and analysis procedure}

We now summarise the recommended modeling and analysis procedure, concentrating on the risk identification section of the ISO 31000 recommendations (IOS, 2009 a,b).

\section{Modelling}

Using the architecture of Figure 3 as a guideline, establish an influence diagram detailing the physical realities of the system-in-focus together with the associated social and political contexts. We favour the Vensim() software (Ventana Systems, 2017) for this purpose, although there are other graphic interfaces available.

Here we have used existing published papers (See Table 1 - 3rd column) with a simple textual analysis to adumbrate appropriate system variables. In general, the extensive extant literature available for EVD will not be present and focus groups, commonly used in the building of such IDs, are an appropriate replacement. The production of these diagrams is therefore, inevitably a negotiation among members of the focus group. This has both advantages and disadvantages in that, on the one hand, the process of surfacing different perceptions of the system structure leads to an improves collective understanding of that system (Coyle, 1996). On the other hand, there will be alternative interpretations of the system details, particularly from the point of view of subsequent observers who were not party to the originating discussions.

The ID, then, should be viewed more as a visual transcript of a set of converging views, rather than as a (positivist) image of an undebatable reality. This indeterminacy is a consequence of the plural nature of two of the subsystems (social context and political policy of Figure 3 ).

\section{Key dynamic processes}

Using the well-documented methods of QSD (Powell and Coyle, 2005; Howard et $a l, 2007)$ extract those closed cycles of causality (dominant loops) which are significant in the operation of the system-in-focus. This is best done by a combination of automatic and inspection methods. These loops can conveniently be categorized by their speed of operation and strength of influence on the overall system outputs as judged by the stakeholders.

\section{Human agency}


For key (dominant) loops identify the human agents who have control over the behaviour of that loop.

\section{Knowledge categorisation and identification}

By consideration of the rôle of each human agent (individual or group) in the operation of dominant loops, establish what knowledge is deployed in that rôle.

5. Loop Analysis and threat identification

Each (dominant) loop is then examined, arrow-by-arrow to determine what would be the effect of disruption to the availability, timeliness or veracity of the knowledge identified so as to disrupt the operation of that component of each loop.

This process can be time-consuming and should be carried out to a depth sufficient to ensure threat analysis of all significant dynamic loops is completed. As with any risk analysis, judgment must be applied as to the resource appropriate for the task. In general terms it is necessary to analyse fully all those loops which are judged by the informants to be significant to the system outputs.

6. Further analysis

There are a number of further analyses which can be done, the details of which we leave to later work. These are aimed at the mitigation and consequence/effect management parts of the process. As far as risk and threat identification are concerned, a useful further activity is to gather together the threat intervention mechanisms for each threat or factor. This then provides a convenient focus for the assessment and management of the threats and risk factors for the system.

\section{Building the model}

The Ebola outbreak has three main sub-models, consonant with the architecture of Fig 3. These are: a local health care sub-model (See Figure 4), focusing on disease transmission mechanisms and the immediate realities of health care; a regional economy sub-model (Fig 5), containing many of the socially constructed variables expected in the situation; and a global issues sub-model (Fig 6) which illustrates some of the wider context of the outbreak into the immediate context of the developed world (DW). The entire model is shown for completeness as Figure 7.

Certain variables in all the figures are truncated for space reasons. For example, in Figure 4 the variable 'funding for drugs' would more properly be expanded to 'funding for drugs, therapeutics and vaccines' which covers non-drug treatments such as convalescent plasma. 


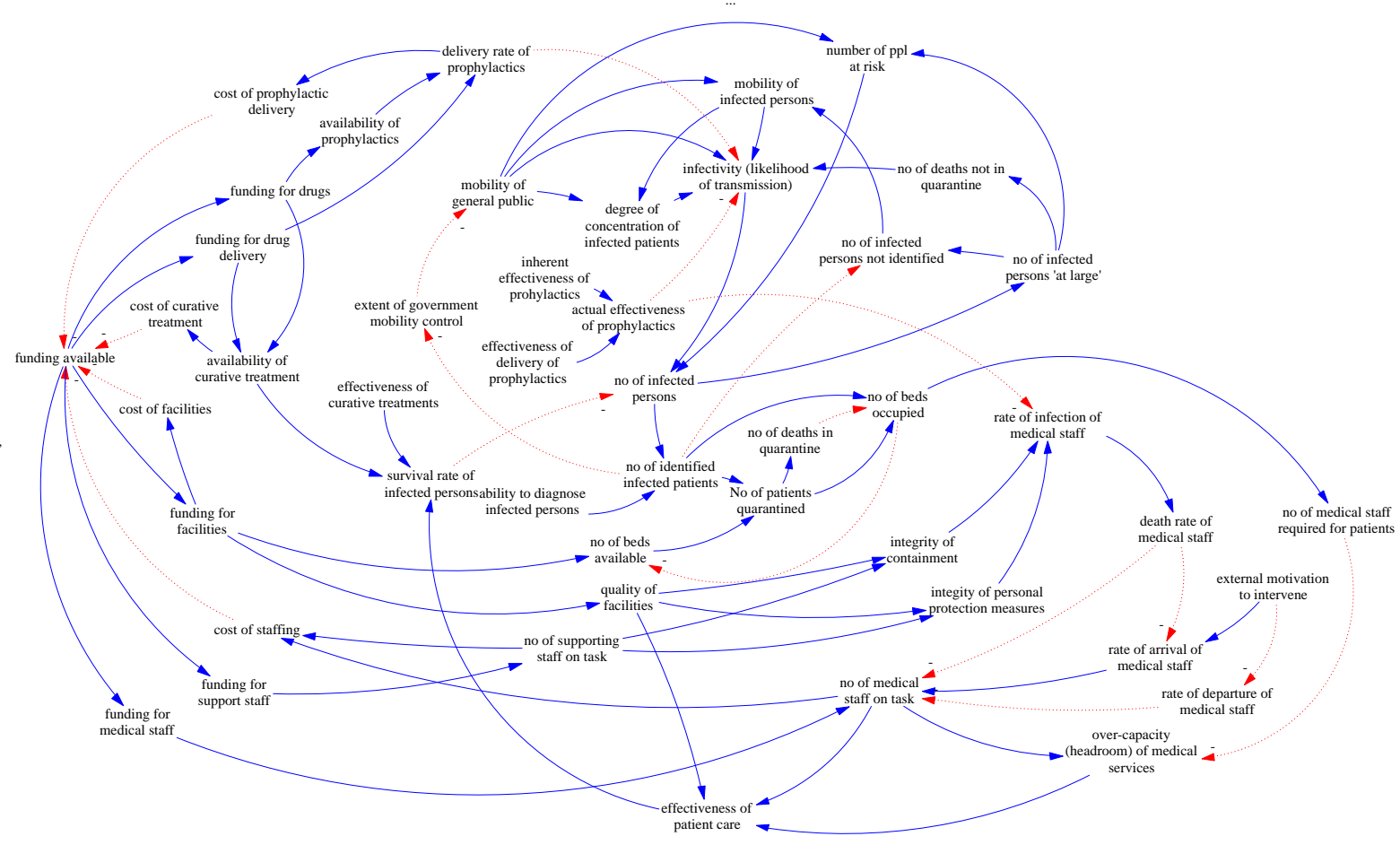

Figure 4: Local health care sub-model

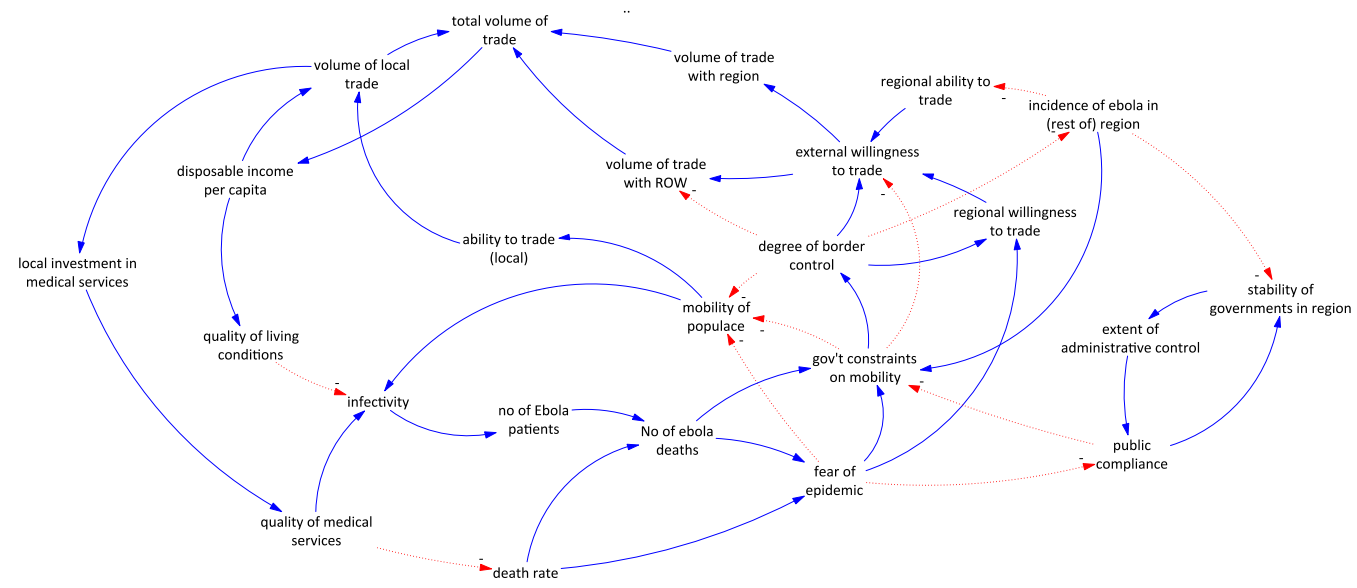

Figure 5: Regional economy sub-model 


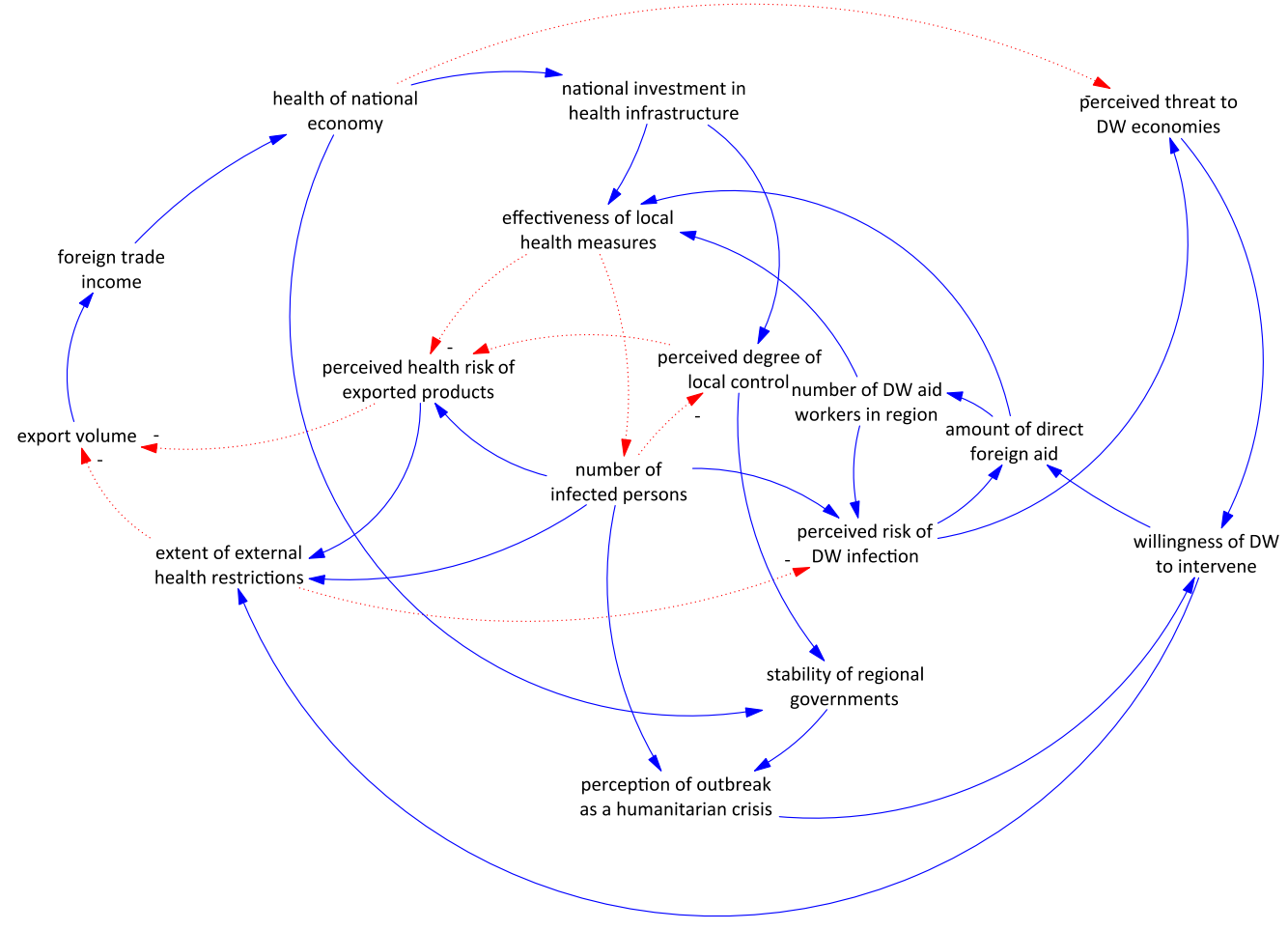

Figure 6: Global issues sub-model

The sub-models are created by examining the issues described in the extensive literature on the outbreak. Table 1 shows an extract from this textual analysis, whereby variables in the ID emerge from examination of key descriptive passages in the papers, most of which were written by firsthand observers of the system in focus. Additionally, one of the authors of the paper, having firsthand experience of Ebola incountry (Sierra Leone), has verified the structure of the model. We are, therefore confident that, at least for the purposes of this risk identification example, the ID model of the outbreak is sufficiently robust.

Table 1 near here

It will be noted that the level of detail in the local health care system sub-model (Fig 4 ) is substantially greater than that of the others. There are two (connected) reasons for this, neither of which is necessarily desirable; firstly the majority of the papers available, and therefore accessed, were written from the perspective of health care workers either on the ground and dealing with the brutal human effects of the outbreak or concerned with the direct support of these health workers; secondly, the management of such an outbreak inevitably is centred in the detailed management of the events and issues on the ground. To some extent the surrounding systems of regional economic management/influence and global effects can be aggregated, where the detailed management of the outbreak cannot.

Inevitably, there is a degree of interpretation by the ID constructors as to the level of detail appropriate. An example of this is the interpretation within the model of 'failure 
to recognise the epidemic early' (Table 1 column 2 first row) in terms of the diagnostic capacity of the staff in the ground (as 'ability diagnose infected persons. While to the lay person these may seem separate, to the experts in the field the appearance of even one case of Ebola would trigger an immediate assumption of the risk of epidemic.

The full model of the Ebola outbreak used to carry out the risk identification is shown, for completeness, in Annex A (full page Fig 10)).

\section{Local health care}

This sub-model, central to the representation of the EVD outbreak, is generic in the sense that it can be applied to any of the subject societies. It is an amalgam of observations deriving from the outbreaks in Zaire (Anon, 1978b; Breman et al, 1978; Team RoaWIS, 1978) , Northern Uganda (Anon, 2001; Borchert et al, 2011; CDC, 2001, 2014; Francesconi et al, 2003; Hewlett and Amola, 2003; Raabe et al, 2010) and the DRC (Anon, 2003; Chowell et al, 2004; Dowell et al, 1999; Kersteins and Matthys, 1999; Khan et al, 1999; Muyembe-Tamfumm et al, 1999) as well as the West African outbreak itself (Dixon and Schafer, 2014; Merler et al, 2015; Nishiura and Chowell, 2014; WHO Ebola Response Team, 2014; Yamin et al, 2015).

In spite of its apparent convoluted nature the sub-model is not difficult to interpret. On the left-hand side, centred on the variable funding available, a set of connections in solid line lead to a number of applications of that funding, viz. funding for drug, therapeutics and vaccine delivery, funding for drugs, therapeutics and vaccines, funding for facilities, funding for clinical staff and funding for support staff. Such solid arrows indicate positive correlation between the variables at each end of the arrow, so that it is understood to mean that an increase in funding available will provoke an increase in the other variables above. There is no assumption of degree strength or speed of connection in this qualitative modelling method (Powell, and Swart, 2005; Howard et al, 2007).

Costs such as cost of staffing (top left hand side of Fig 4) connect in to funding available with a dotted arrow, indicating a negative correlation, so that as costs rise, they diminish the funds available.

Even in this localized area of Fig 4 we can see some simple examples of the structures on which qualitative system dynamics analysis rests, namely the resonant dynamic structures known as loops. Figure 7 shows a small extract from Figure 4.

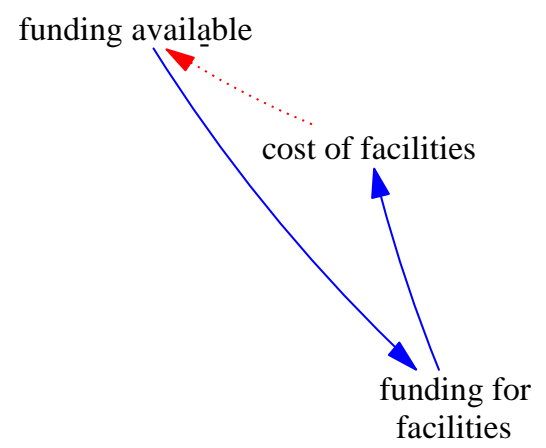

Figure 7: Loop extracted from local health care sub-model - Loop 01

Here we see a typical closed structure called a loop in which, as costs are incurred, the available (remaining) funding for facilities is reduced. We will see other more complex and significant ones later in the analysis. This loop of figure 7 is a goal 
seeking or compensating loop, since its operation is such that a small increase in one variable will tend to a decay in its effect as time progresses. Other, very significant loops exhibit runaway characteristics, where a small change in one variable, rather than dying out, propagates in a resonant fashion.

Two of these, loops 02 and 03 can be seen in Figure 7 towards the centre of the diagram.

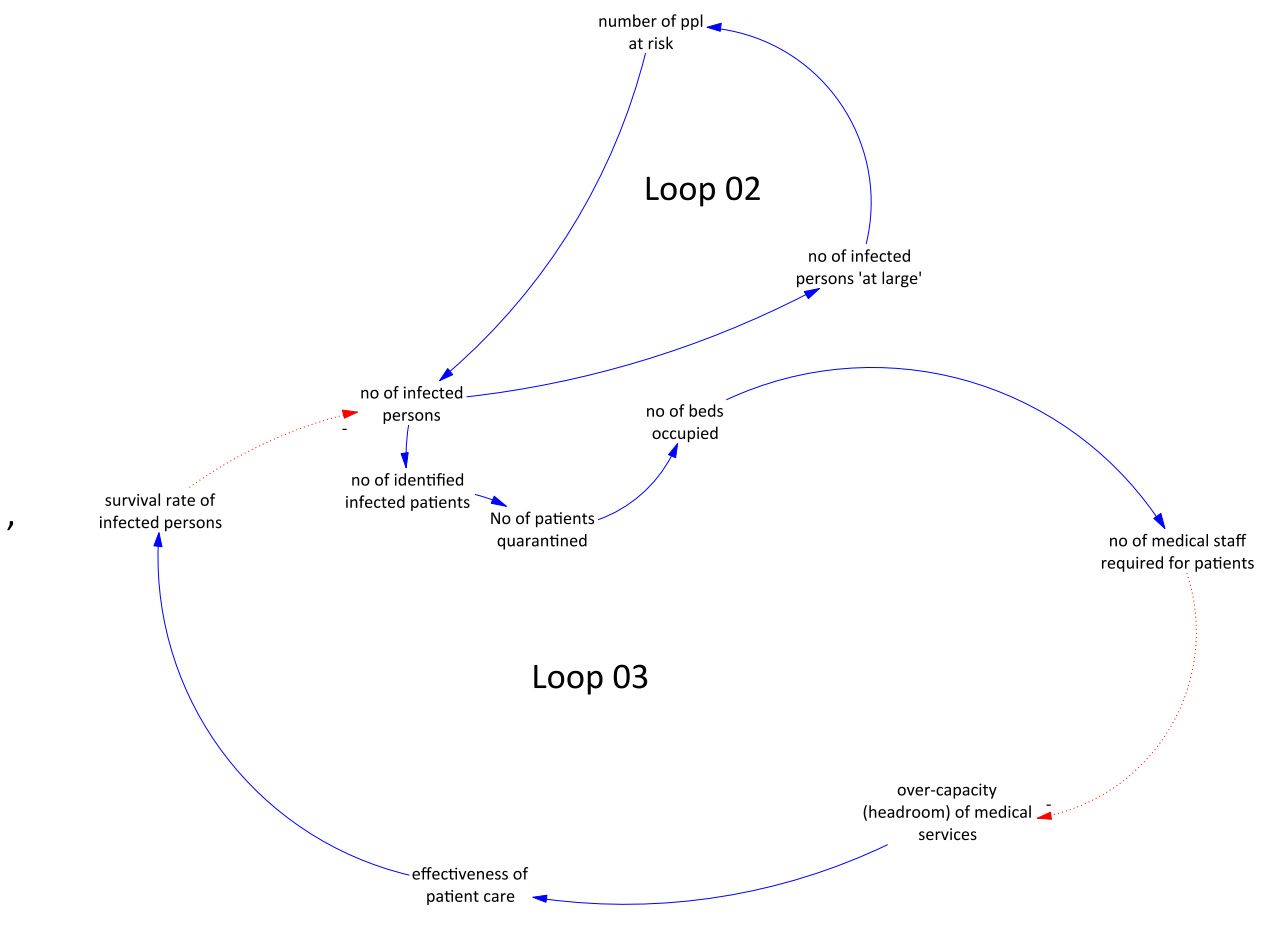

Figure 8: Two runaway loops from the local health care sub-model

The action of Loop 02 is straightforward: as the no of infected persons increases, the number of infective persons in the population concomitantly increases (no of infected persons 'at large'), raising the number of people in contact with the virus and hence the no of infected persons is further raised. This is in a sense the central aetiological mechanism of epidemic dynamics, as illustrated in Figure 2. Without intervention, the number of infected persons will rise without limit until the at-risk population is expended.

Loop 03 requires a little more explanation: as the no of infected persons rises the number identified rises, leading to an increase in the no of patients quarantined. This leads to an increase in the no of beds occupied which places a demand on the number of medical staff required for patients, thus reducing the spare capacity (over-capacity (headroom) of medical services). Additionally, as the number of beds available decreases, the ability to isolate infected community members also decreases, putting hospitals and uninfected community groups at greater risk. As a result, the effectiveness of patient care reduces which reduces the survival rate, meaning that the no of infected persons at large increases.

Both Loop 02 and 03, then, represent run-away processes, which, if unchecked, would, in the first case lead to massive untreated infection in the community and in 
the second, to an overload of the medical system with similar infective consequences. Of course, mechanisms in the rest of the system will have an effect on these isolated mechanisms. Nevertheless, the identification of these important mechanisms provides both a basis for managerial action and, in the case of the focus of the present paper, the focus for the identification of risks, since, if we can assess the likelihood and mechanisms of disruption of the key dynamics as represented by these loops, we have a sound basis for risk identification and effects analysis.

\section{Regional economy}

Figure 5 shows the sub-model dealing with the local regional issues. It contains variables dealing with both the local economic effects (such as disposable income per capita and volume of local trade) and with some of the interaction between the region and the local economy. In particular, the degree of control by the governments of the affected region on population movement both within the local economies (mobility of populace) and within each country (degree of border control) are represented. The effect of stability of the relational governments can be explored through loops passing through the variable stability of governments in region (right hand side of Fig 5).

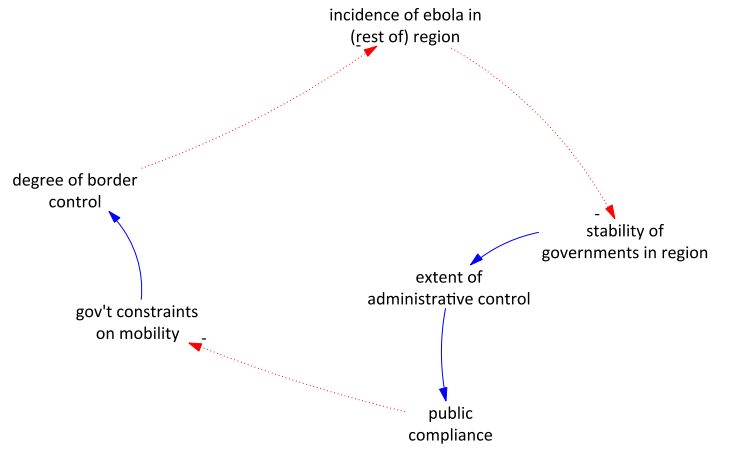

Figure 9: Loop 04, showing an effect of the political stability in the region

Loop 04 extracted from the right-hand side of Figure 9 shows that if the incidence of Ebola in the region rises political stability will fall, reducing the extent of administrative control and hence public compliance. Governments will then react by increasing their imposed constraints on public mobility including border control, which, in time, will reduce the rate of arrival of infected persons and reduce the incidence of Ebola. This loop, 04, is a compensating loop, which, while not as powerful a source of a managerial intervention agenda as is a run-away loop, nevertheless provides a source of analysis for risks. Loop 04 is counterintuitive in that, viewed from the perspective of a situation manager, it is desirable for there to be a degree of political instability, since this will induce more effective border controls There are, of course, both desirable and undesirable effects of such instability, which can be deduced from examination of Figure 5.

\section{Global issues}

Figure 6 shows the effects of the global economic issues, important here because of the inevitable connection between the outbreak in the region and the economy of the 
developed world (DW). The connection with local issues is clearly seen; for example in the presence of variables such as effectiveness of local health measures and stability of regional governments. Examination of Figure 6 how the likely effect on the DW (perceived threat to DW economies) determines the willingness of the DW to intervene, an obvious but often unexplored connection.

This last variable, stability of regional government, also appears in Figure 5, allowing a bridge between the two sub-models, and is an example of how the three sub-models are concatenated, by combining common variables, to form the somewhat dense full model of Figure 10, to be found in Annex A.

There are several examples of action dilemmas at all levels of governance. At any point in the accelerating outbreak there are both 'known knowns', such as current number of daily new cases.; There are the possibly predictable 'known unknowns', such as what is the number of new cases to be seen in a month if safe isolation and treatment capacity is not increased and community transmission continues unabated. And there are the near 'unknowable unknowns', such as what will happen if a crisis is declared, borders are closed and transport limited which may possibly limit spread but will undoubtedly have detrimental political and economic ramifications. The same is true at on-the-ground control measures - without ability to discern whether an increase in isolation and treatment facility bed spaces, investment in diagnostic centres, community engagement and messaging, safe burial facilities, or some combination of the above will best impact on outbreak control, either poorly timed or misjudged investments may be made. Such complex decision-making occurs in fastpaced, stressed environments, often without clear comparators or models of effectiveness, and with competing interests - rapid disease containment versus overall country functioning. Decision paralysis is therefore prone to occur, and often only by playing out various loops and analyzing strategic vulnerabilities in advance will help mitigate this system's functioning. The answers may clearly be very different at each stage of outbreak response and must be re-assessed constantly throughout. There is also the very real problem of the 'Black Swan' phenomena of the complete 'unknown unknowns', (Osterholm et al, 2015) such as what would happen if a simultaneous, similar-size EVD outbreak was introduced into the Indian or Chinese subcontinent, or a global influenza pandemic coincided with peak EVD transmission. We must at least think of the possibility of these scenarios to determine how they may curtail individual control efforts.

\section{Identification of key dynamics}

The identification of the key dynamic mechanisms of a system dynamics ID is a wellknown problem, which is approached by a combination of automatic methods and visual inspection. In general, the analyst seeks to identify sufficient loops as to cover the diagram, but there is an element of judgment applied in selecting an ensemble of loops such that the key dominant mechanisms are captured. In the EVD example, some 25 loops of varying significance were identified. In order to illustrate of the risk identification process, from here on, we select two loops for detailed analysis, one being centered on the local health issues (Loop 03 of Fig 8, extracted from the submodel of Fig. 4) and one on the regional scene of Figure 5 (loop 04, extracted from the sub-model of Figure 6) but the process is identical for however many loops are deemed to be significant by the analyst. 


\section{Risk identification}

Tables 2 and 3 (full page) show the risk identification process followed.

Tables 2 and 3 near here

In its simplest form, for each loop, the tables identify (column 2) the agents who have influence over the strength of activity in the loop. There are more sophisticated analysis steps which can be include which take into account the strength and speed of each loop's operation (Powell et. al., 2016). While this improves the analyst's ability to weigh risks one against the other and is particularly recommended at the stage of loop selection, it does not affect the risk identification stage of the analysis presented here.

Column 3 shows both the tacit and explicit knowledge deployed by those agents in the particular loop. One of the strengths of the method presented here is the specific consideration of tacit knowledge. It is relatively easy to appreciate how explicit, codified, overtly communicated knowledge is used in a crisis (for example, here, the scientifically-derived symptomatology of EHF needed by a number of parties not all of whom are medically trained (Police $(\mathrm{P})$, family members $(\mathrm{F})$ and local leaders (LL), for example). It is less obvious without the level of analysis proposed here what the rôle is of the tacit knowledge, such as the need for the police to balance their commitment to 'business as usual' crime prevention vis-à-vis the detection of infected persons, or at a more subtle level, the detection of suspicious behaviour in the immediate relatives of infected persons and the inference of the presence of a possible EHF victim.

Some of these knowledge requirements are obvious to holders of the function but not necessarily to risk analysts. For example, the varieties of diplomatic knowledge required on the part of agent IN in table 3 (the international diplomatic effort) is a mixture of obvious legal and procedural knowledge of the accepted diplomatic channels and protocols, with a component of tacit knowledge to do with the way in which West African diplomats will react in the particular circumstances of the Ebola outbreak. None of this will be foreign to skilled diplomats, but may well not be expressed in a full risk analysis by a non-diplomat.

Column 4 of the table is an extraction of the key risks emerging specifically from the knowledge analysis. Inevitably the risks explicated in Column 4 have a value judgment associated with them deriving from both an inherent understanding of the importance of the mechanisms implied by the loop selection and the effects of the absence of the knowledge identified in Column 3 on the loop behaviour.

As is the case with much risk identification work, only a small fraction of the risks identified in column 4 will be enacted in any particular situation. In the outbreak under discussion here there are many examples of knowledge failure of a predictable nature, such as the effect of press coverage on public opinion in an unexpected way (Table 3, agent $\mathrm{P}$ ) or the early failure of medical staff to deploy some of their number on case detection in the community rather than the treatment of identified patients (Table 2, agents $\mathrm{M}$ and $\mathrm{P}$ ). Other events in the Ebola outbreak were less predictable. For example, the riots of 20 August 2104 in Liberia (New York Times, 2014), resulting (on this analysis) from a knowledge failure of the effects of the true state of morale in the population (Table 3, agent EX) and of the appropriate use of Aid to the Civil Power, or ACP (Table 3, agent, EX) were demonstrably not predicted by the administration of Liberia. 


\section{Utility and role of approach - Discussion and Future Development}

The management of knowledge in an organisation, while essential to its success, is not the only focus for strategic management. Similarly, the identification of risks emerging from knowledge failure forms only part of the overall risk identification processes emerging from a wider consideration (Powell et al, 2016). Nevertheless, the risks deriving from failure to provide knowledge at the time and point of use is, we submit, as important as information failures and other mechanisms. In the Ebola case here, for example, the failure of the medical workers to understand the importance of detecting the presence of, identifying and extracting for quarantine, unreported cases in the population proved almost catastrophic in some of the West African countries. In Nigeria, however, where that knowledge was both available and acted upon, the effect on infectivity of undetected infected patients was significantly less and contributed to the substantially more effective epidemic control performance in that country.

The purpose of this paper has not been to show a better model of the Ebola outbreak, although the system model of Figures 2,3, 4 and 9 has been verified against the multitude of reports available (Fisman et al, 2014; Legrand et al, 2007; Lewnard et al, 2014). Neither has it been to advocate the sole use of a knowledge-based risk identification procedure. Rather, we present a response to the relative paucity of knowledge based risk identification in a complementary manner to more general approaches, such as that of Cook and Rasmussen (2015). The analysis of the relatively complex crisis of Ebola in West Africa illustrates the usefulness of this knowledge-based approach. Work continues both to establish the transferability of this approach to other epidemics and related crises, with an emphasis on the pre-crisis appreciation of risk (ECDPC, 2015) and on a generalised crisis model, probably restricted to medical crises, which can be compared with existing practice in risk containment. The extension of the technique towards specific response identification would seem worthwhile.

It can be argued that the qualitative approach described here is limited in the precision of its representation when compared with a qualitative approach. This debate has been active in the system dynamics community for a considerable time (Coyle 1996; Ackermann et al, 2014). Both approaches co-exist within that community for good reasons; while the quantitative form of system representation does indeed produce precision when and where the variables can be made numerical, but, in many cases, such numerical representation is not available to the modeller. We assert that such is the case of risk identification and assessment specifically, because of the nature of the three intersecting subsystems identified in Figure 3. It will be possible to represent sub-dynamics of the risk system, particularly within the physical subsystem of Fig 3, but if risk identification were to be limited to those aspects which are quantifiable, large areas of identifiable risk will fail to be identified. It is our contention that the approach described here provides a useful scoping technique within which specific numerical approaches can subsequently operate. 


\section{References}

Ackermann F, Howick S, Quigley J, Walls L and T Houghton (2014) Systemic Risk elicitation: Using causal maps to engage stakeholders and build a comprehensive view of risks European J of OR Vol 238 iss 1 pp290-299

Ackermann F, Eden C, Williams T and S Howick (2007) Systematic risk assessment: a case study $J$ Opl Res Soc Vol 58 pp39-51

Adams, J Risk Routledge 1995

Airmic / Alarm / IRM (2010) "A structured approach to Enterprise Risk Management (ERM) and the requirements of ISO 31000"

http://www.theirm.org/documents/SARM_FINAL.pdf

Anon (1978) Ebola haemorrhagic fever in Sudan, 1976 Report of a

WHO/International Study Team. Bulletin of the WHO 56 pp 247-270

Anon (1978) Ebola haemorrhagic fever in Zaire, 1976 Bulletin of the WHO 56 pp27123

Anon (2001) Outbreak of Ebola haemorrhagic fever, Uganda, August 2000-January 2001. Weekly Epidemiological Record. 76 pp 41-46

Anon (2003) Outbreak(s) of Ebola haemorrhagic fever in the Republic of Congo, January - April 2003. Weekly Epidemiological Record 78 pp 285 - 289

Apgar, D. (2006), Risk Intelligence: Learning to Manage What We Don't Know, Harvard University Press,Boston, MA.

Ashfaq M,Khan N, Saif Ur Rehamn M, Mustafa G, Faizan Nazar M,Sun Q, Iqbal J, Mulla, SI and C-P Yu (2017) Ecological risk assessment of pharmaceuticals in the receiving environment of pharmaceutical wastewater in Pakistan Ecotoxicology and Environmental Safety Vol 136, February 2017 pp31-39

Aven T (2016) Risk assessment and risk management: Review of recent advances on their foundation European $J$ of $O R$ Vol 253 iss 1 pp1-13

Aven T (2013) Practical implications of the new risk perspectives Reliability Engineering and System Safety Vol 115, July 2013 pp 136-145

Bachani AM, Hung YW, Mogere S, Akungah D, Nyamari J, Stevens KA, and Hyder AA (2017) Prevalence, knowledge, attitude and practice of speeding in two districts in Kenya: Thika and Naivasha Catena 149(1 Feb 2017) pp426-436

Baron RC, McCormick JB, Zubeir OA. (1983) Ebola virus disease in southern Sudan: hospital dissemination and intrafamilial spread. Bull World Health Organ.61:9971003

Baumard, P. (1999). Tacit knowledge in organisations. London, Sage

Benoit A, Bernard JG, Carlos CG (2011) Defining Knowledge Management System Risk. Proc. Pacific Asia Conference on Information Systems (PACIS)

Berger, P., Luckmann, T., 1966. The Social Construction of Reality. Allen Lane, London.

Bogoch II, Creatore MI, Cetron MS, Brownstein JS, Pesik N, Miniota J, Tam T, Hu W, Nicolucci A, Ahmed S, Yoon JW, Berry I, Hay SI, Anema A, Tatem AJ, 
Borodzicz, Edward (2005). Risk, Crisis and Security Management. New York: Wiley. ISBN 0-470-86704-3.

Borchert M, Mutyaba I, Van Kerkhove MD, et al. (2011) Ebola haemorrhagic fever outbreak in Masindi District, Uganda: outbreak description and lessons learned. BMC Infect Dis. 11:357.

Boy G and Y Barna (2005) Knowledge Management in the Design of Safety-Critical Systems (in Encyclopedia of Knowledge Management, Idea Group, Inc., Hershey, PA, USA

Breman JG, Piot P, Johnson KM, et al. (1978) The epidemiology of Ebola hemorrhagic fever in Zaire, 1976. In: Pattyn SR, editor. Ebola virus haemorrhagic fever. Elsevier Science; Amsterdam. pp. 85-97.

Brown CS, Houlihan C, Lado M, Mounter N, Youkee D. (2017) What do we know about controlling Ebola Virus Disease outbreaks? Retrovirology 2017 (In press)

Busby JS, Onggo BSS and Liu Y (2016) Agent-based computational modelling of social risk responses Eur J of OR 253(1) pp 1-13

Cafod (2015) http://www.cafod.org.uk/News/Emergencies-news/Ebola-yourquestions-answered?) accessed May 152015

CDC (2001) Outbreak of haemorrhagic fever Uganda August 2000-January 2001. Morbidity and Mortality Weekly Report 50 pp 73-77

CDC (2014) Centers for Disease Control and Prevention: Ebola outbreaks 2000-2014. 2014 http://www.cdc.gov/vhf/ebola/resources/outbreaks.html. Accessed 01 August 2017

CDC (2016) Centers for Disease Control and Prevention. Cost of the Ebola Epidemic. Atlanta: CDC, 2016. Available from: https://www.cdc.gov/vhf/ebola/outbreaks/2014west-africa/cost-of-ebola.html accessed 10 Aug 2017

CDC (2017) Centers for Disease Control and Prevention. Outbreaks Chronology: Ebola Virus Disease. Atlanta: CDC, 2017. Available from:

https://www.cdc.gov/vhf/ebola/outbreaks/history/chronology.html accessed $10 \mathrm{Aug}$ 2017

Check Hayden E. (2014) World struggles to stop Ebola. Nature. Aug 28;512 pp 355-6

Checkland P and Scholes J (1990) Soft Systems Methodology in Action pub J Wiley ISBN 0471927686,9780471927686

Choo, C.W. (1998), The Knowing Organization: How Organizations Use Information to Construct Meaning, Create Knowledge, and Make Decisions, Oxford University Press, New York, NY.

Chowell $\mathrm{G}$ et al. (2004) The basic reproductive number of Ebola and the effects of public health measures: the cases of Congo and Uganda J. of Theoretical Biology 229 pp 119-126

Cook, R; Rasmussen, J (2005) Quality and Safety in Health Care, Vol 14(2) (April) pp 130-134 "Going solid" a model for system dynamics and consequence for patient safety 
Coyle, R. (1996) Systems Dynamics Modelling: A Practical Approach (Chapman \& Hall, London).

Crockford, Neil (1986). An Introduction to Risk Management (2 ed.). Cambridge, UK: Woodhead-Faulkner. p. 18. ISBN 0-85941-332-2.

Davenport, T. and Prusak, L. (1998), Working Knowledge: How Organizations Manage What They Know, Harvard Business School Press, Boston, MA.

De Zoysa, S. and Russell, A.D. (2003), “Knowledge-based risk identification in infrastructure projects" Canadian Journal of Civil Engineering Vol. 30 No. 3, pp. 51122.

Dixon MG, Schafer IJ (2014) Ebola viral disease outbreak--West Africa, 2014. MMWR Morb Mortal Weekly Rep. Jun 27;63(25) pp 548-51.

Dorfman, Mark S. (2007). Introduction to Risk Management and Insurance (9 ed.). Englewood Cliffs, N.J: Prentice Hall. ISBN 0-13-224227-3.

Dowell SF, Mukunu R, Ksiazek TG, Khan AS, Rollin PE, Peters CJ. (1999)

Transmission of Ebola hemorrhagic fever: a study of risk factors in family members, Kikwit, Democratic Republic of the Congo, 1995. J Infect Dis.;179(Suppl 1):S87S91.

ECDPC (2015) http://reliefweb.int/report/sierra-leone/rapid-risk-assessmentoutbreak-ebola-virus-disease-west-africa-10th-update-14 Rapid risk assessment: Outbreak of Ebola virus disease in West Africa. 10th update, 14 April 2015 (accessed 21/9/2015)

Eden, C. (1989) Using Cognitive Mapping for Strategic Options Development and Analysis (SODA) in Rational Analysis for a Problematical World (ed. Rosenhead, J.) (Wiley, Chichester).

Farrar JJ, and Piot P (2014) The Ebola Emergency - Immediate Action, Ongoing Strategy N England J Med 371:1545-1546

Fisman D, Khoo E, Tuite A. (2014) Early epidemic dynamics of the West African 2014 Ebola outbreak: estimates derived with a simple two-parameter model. Plos Currents Outbreaks. http://currents.plos.org/outbreaks/article/obk-14-0036-earlyepidemic-dynamics-of-the-west-african-2014-ebola-outbreak-estimates-derived-witha-simple-two-parameter-model/

Folashade B Agusto, Miranda I Teboh-Ewungkem, and Abba B Gumel (2015) Mathematical assessment of the effect of traditional beliefs and customs on the transmission dynamics of the 2014 Ebola outbreaks BMC Medicine 15; $13: 96$

Francesconi P et al. (2003) Ebola hemorrhagic fever transmission and risk factors of contacts, Uganda. Emerging Infectious Diseases 9 pp 1430-1437

Frost, A., (2014). A synthesis of knowledge management failure factors. www.knowledgemanagementtools.net accessed 1 Aug 2017

Gatherer D (2015). The unprecedented scale of the West African Ebola virus disease outbreak is due to environmental and sociological factors, not special attributes of the currently circulating strain of the virus. Evidence Based Medicine Feb;20(1):28. 
Georges A-J, Leroy EM, Renaut AA, et al. (1999) Ebola hemorrhagic fever outbreaks in Gabon, 1994-1997: epidemiologic and health control issues. J Infect Dis. 179(Suppl 1):S65-S75.

Gillespie AM, Obregon R, el Asawri R, et al. (2016) Social Mobilization and Community Engagement Central to the Ebola Response in West Africa: Lessons for Future Public Health Emergencies. Glob Health Sci Pract 2016;4(4):626-646.

Goerlandt F, Goite H, Valdez Banda OA, Höglund A, Ahonen-Rainio and M Lensu (2017) An nlaaysis of wintertime navigational accidents in the Northern Baltic Sea Safety Science Vol 92 February 2107 pp 66-84

Gomes MFC, Rossi L, et al. (2014) Assessing the international spreading risk associated with the 2014 West African Ebola outbreak. Plos Currents Outbreaks. http://currents.plos.org/outbreaks/article/assessing-the-international-spreading-riskassociated-with-the-2014-west-african-ebola-outbreak/

Hewlett BS and Amola RP (2003) Cultural contexts of Ebola in Northern Uganda. Emerging Infectious Diseases 9 pp 1242-1248

Hillson D and Murray-Webster, R (2007). Understanding and Managing Risk Attitude. Gower Publishing, Ltd. ISBN 978-0-566-08798-1.

Hopkin, Paul (2012) "Fundamentals of Risk Management 2nd Edition" Kogan-Page ISBN 978-0-7494-6539-1

Houlihan CF, Youkee D, Brown CS. (2017) Novel surveillance methods for the control of Ebola virus disease. Int Health 2017;9(3):139-141.

Howard M, Vidgen R, Powell P and Powell JH (2007) Exploring the use of QPID: A collaborative study of $\mathrm{B} 2 \mathrm{~B}$ in the automotive industry Omega, Volume 35, Issue 4, August 2007, pp 451-464

Hubbard, D (2009). The Failure of Risk Management: Why It's Broken and How to Fix It. John Wiley \& Sons. p. 46.

Ishikawa A and I Naka (2003) Knowledge management and risk strategies pub. World Scientific Publishing Co. Pte. Ltd

IOS(20090a) ISO/DIS 31000. Risk management - Principles and guidelines on implementation. International Organization for Standardization.

IOS (2009b) ISO/IEC Guide 73:2009 (2009). Risk management - Vocabulary. International Organization for Standardization.

Kerstiens B, Matthys F (1999) Interventions to control virus transmission during an outbreak of Ebola haemorrhagic fever: experience from Kikwit, Democratic Republic of the Congo, 1995. J. of Infectious Diseases 179:S263-267

Khan AS, Tshioko FK, Heymann DL, et al. (1999) The reemergence of Ebola hemorrhagic fever, Democratic Republic of the Congo, 1995. J Infect Dis.;179(Suppl 1):S76-S86.

Legrand J, Grais RF, Boelle PY, Valleron AJ and Flahault A (2007) Understanding the dynamics of Ebola epidemics Epidemiology and Infection 135(4) pp 610-621

Lewnard JA, Ndeffo Mbah ML, Alfaro-Murillo JA, Altice FL, Bawo L, Nyenswah TG, Galvani AP. (2014) Dynamics and control of Ebola virus transmission in 
Montserrado, Liberia: a mathematical modelling analysis. Lancet Infectious Diseases Dec;14(12):1189-95.

Lou H, Yang S, Zhao C, Wang Z, Shi L, Wu L, Dong G, Cai M, Hao F and Sun Y (2017) Using a nitrogen-phosphorus ratio to identify phosphorus risk factors and their spatial heterogeneity in an intensive agricultural area Renewable and Sustainable Energy Reviews 68 (1 Feb 2017) pp 33-47

MacFadden D, German M, Khan K (2015). Assessment of the potential for international dissemination of Ebola virus via commercial air travel during the 2014 West African outbreak. Lancet. Jan 3;385(9962) pp 29-35 Trop Med Int Health. 2002;7:1068-75

Massingham P (2010) Knowledge risk management: a framework J of Knowledge Management Vol 14 iss 3 pp464-485

McDonald G, Harford B, Arrivilaga A, Babcock EA, Carcamo R, Foley J, Fujita R, Gedamke T, Gibson J, Karr K, Robinson J and Wilson J (2016) An indicator-based adaptive management framework and its development for data-limited fisheries in Belize Eur J of OR 251(3) pp 1029-1042

Merler S, Ajelli M, Fumanelli L, Gomes MF, Piontti AP, Rossi L, Chao DL, Longini IM Jr, Halloran ME, and Vespignani A (2015) Spatiotemporal spread of the 2014 outbreak of Ebola virus disease in Liberia and the effectiveness of nonpharmaceutical interventions: a computational modelling analysis. Lancet Infectious Diseases. Feb; 15(2) pp 204-11

Moteff, J (2005). Risk Management and Critical Infrastructure Protection: Assessing, Integrating, and Managing Threats, Vulnerabilities and Consequences (Report).

Washington DC: Congressional Research Service.

MSF (2015) An effective Ebola intervention: The Foya approach http://www.msf.org.uk/an-effective-ebola-intervention-the-foya-approach (accessed 21/9/2015)

Muyembe-Tamfumm JJ et al. (1999) Ebola outbreak in Kikwit, Democratic Republic of the Congo: discovery and control measures J. of Infectious Diseases 179: S259-262

Ndambi R et al (1999) Epidemiological and clinical aspects of the Ebola virus epidemic in Mosango, Democratic Republic of Congo, 1995 J of Infectious Diseases 179:S8 - S10

Nederpelt, Peter van (2012). Object-oriented Quality and Risk Management (OQRM). A practical and generic method to manage quality and risk. MicroData. ISBN 978-1291-037-35-7.

New York Times (2014) Clashes erupt as Liberia sets an Ebola Quarantine http://www.nytimes.com/2014/08/21/world/africa/ebola-outbreak-liberiaquarantine.html? r=0 Accessed 19 October 2015

NIOSH - National Institute for Occupational Safety and Health (1998). System Safety and Risk Management: A Guide for Engineering Educators. Cincinnati, $\mathrm{OH}$. 
Nishiura H, Chowell G. (2014) Early transmission dynamics of Ebola virus disease (EVD), West Africa, March to August 2014. Euro Surveill. Sep 11;19(36):20894.

Osterholm MT, Moore KA and Gostin LO (2015) Public Health in the Age of Ebola JAMA Intern Med. 2015;175(1):7-8. doi:10.1001/jamainternmed.2014.6235.

Polanyi, M. (1966) in Grene, M. (Ed.), The Logic of Tacit Inference. Knowing and Being, Essays by Michael Polanyi, Routledge \& Kegan Paul, London.

Powell, JH and Coyle, RG (2005) Identifying strategic action in highly politicised contexts using agent-based qualitative system dynamics. J of Operational Research Society,56, pp 787-798.

Powell JH and Swart, J (2005) Men and measures: using qualitative system modelling to map knowledge in firms $J$. of the Operational Research Society, 2005 57, pp10-21

Powell, J H and Swart J, (2010) Mapping the values in B2B relationships: a systemic, knowledge-based perspective. Industrial Marketing Management, 201039 (3), pp. 437-449

Powell JH, Mustafee N, Hammond M and Chen, (2016) A System-focused risk identification and assessment for disaster preparedness: Dynamic threat analysis European Journal of Operational Research, Volume 254, Issue 2, 16 October 2016, pp 550-564

Powell JH, Mustafee N, Hammond M and Chen A (2017) Human agency in disaster planning: a systems approach (in preparation, submitted to Risk Analysis)

Raabe VN, Mutyaba I, Roddy P, Lut-wama JJ, Geissler W, Borchert M. (2010) Infection control during filoviral hemorrhagic fever outbreaks: preferences of community members and health workers in Masindi, Uganda. Trans $R$ Soc Trop Med Hyg.;104:48-50

Raut RD, Narkhede B, Gardas BB (2017) To identify the critical success factors of sustainable supply chain management practices in the context of oil and gas industries: ISM approach Marine Policy 76 (1 February 2017) pp 28-37

Reece S \& Brown CS, Dunning J, Chand MA, Zambon MC, Jacobs M. (2017) The UK's multidisciplinary response to an Ebola epidemic. Clin Med 2017;17(4):332-7.

Riege A (2005) Three dozen knowledge sharing barriers managers must consider $J$ of Knowledge Management Vol 9 No 3 pp19-35

Rowe AK et al. (1999) Clinical virologic and immunologic follow-up of convalescent Ebola hemorrhagic fever patients and their household contacts, Kikwit, Democratic Republic of the Congo. Commission de Lutte contre les Epidemies a Kikwit. J of Infectious Diseases 179:S28-S35

Ruzic-Dimitrijevic L (2014) Risk assessment of knowledge management system Online J of Knowledge Management Vol 3 iss 2 pp114-126

Scarbrough, H., Swan, J., \& Preston, J. (1999). Knowledge management: A literature review. London: Chartered Institute of Personnel and Development (CIPD). 
Scott-Parker B and O Oviedo-Trespalacios (2017) Young driver risky behaviour and predictors of crash risk in Australia, New Zealand and Colombia: Same but different? Accident Analysis and Prevention Vol 99 February 2017 pp30-38

Spiekermann R, Kienberger S, Norton J, Briones F and J Weichselgartner (2015) The Disaster-Knowledge Matrix - Reframing and evaluating the knowledge challenges in disaster risk reduction Int'l J of Disaster Risk Reduction Vol 13 September 2105 pp96-108

STC (2016) Science and Technology Committee. Science in emergencies: UK lessons from Ebola inquiry - UK Parliament. UK Government: London, 2016

Stoneburner, Gary; Goguen, Alice and Feringa, Alexis (July 2002). Risk Management Guide for Information Technology Systems (PDF). Gaithersburg, MD: National Institute of Standards and Technology.

Swart J (2011) That's why it matters: How knowing creates value Management Learning July 2011 vol. 42 no. 3 319-332

Team RoaWIS (1978) Ebola haemorrhagic fever in Zaire, 1976. Bull World Health Organ.;56:271-93.

Tosh PK, Sampathkumar P. (2014) What clinicians should know about the 2014 Ebola outbreak. Mayo Clinical Proc. Dec;89(12) pp 1710-7

Trickey G (2011), Risk Types. OP Matters No 14 February 2012 The British Psychological Society

Tsoukas, H., (1996). The firm as a distributed knowledge system: a constructionist approach. Strategic Management Journal 17, 11-25.

Tsoukas, H., \& Vladimirou, E. (2001). What is organizational knowledge? Journal of Management Studies, 38(7), 973-994.

UNDP (2015)

http://www.undp.org/content/undp/en/home/presscenter/pressreleases/2015/03/12/wes t-african-economies-feeling-ripple-effects-of-ebola-says-un.html accessed May 19 2015

UNISDR (2014) HFA thematic review: Research area 2https://www.unisdr.org/we/inform/publications/49501 accessed Dec 72016

UNISDR(2015a) Global assessment report on disaster risk reduction 2015 https://www.unisdr.org/we/inform/publications/42809 accessed Dec 72016

UNISDR (2015b) Sendai framework for disaster risk reduction https://www.unisdr.org/we/coordinate/sendai-framework accessed Dec 72016

USEPA (2004) General Risk Management Program Guidance. pub. United States Environmental Protection Agency (April 2004) Washington

Uyeki TM, Mehta AK, Davey RT, et al. (2016) Clinical Management of Ebola Virus Disease in the United States and Europe. N Engl J Med 2016;374(7):636-46.

Ventana System (2017) http://vensim.com/ accessed 1 August 2017

Verhagen A (2005) Constructions of Intersubjectivity: Discourse, Syntax, and Cognition Oxford/New York: Oxford University Press, 2005. 
Walsh PD, Biek R and Real LA (2005) Wave-like spread of Ebola Zaire PLoS Biology 2005;3:e371

WHO Ebola Response Team. (2014) Ebola virus disease in West Africa--the first 9 months of the epidemic and forward projections. $N$ Engl J Med. Oct 16;371(16) pp 1481-95

WHO (2016a) World Health Organisation. Statement on the 1st meeting of the IHR Emergency Committee on the 2014 Ebola outbreak in West Africa. Geneva: WHO, 2016. Available from: http://www.who.int/mediacentre/news/statements/2014/ebola20140808/en/ accessed 10 Aug 2107

(WHO 2016b) World Health Organisation. Ebola Situation Report - 30 March 2016. Geneva: WHO, 2016. Available from: http://apps. who.int/ebola/currentsituation/ebola-situation-report-30-march-2016 accessed 10 Aug 2017

Yamin D, Gertler S, Ndeffo-Mbah ML, Skrip LA, Fallah M, Nyenswah TG, Altice FL, Galvani AP (2015) Effect of Ebola progression on transmission and control in Liberia. Ann Intern Med. Jan 6;162(1) pp 11-7 
Sources of model variables

\begin{tabular}{|c|c|c|}
\hline Variable in models & Citation & Reference \\
\hline $\begin{array}{l}\text { degree of } \\
\text { concentration of } \\
\text { infected patients } \\
\text { mobility of general } \\
\text { public } \\
\text { infectivity } \\
\text { ability to diagnose } \\
\text { infected persons }\end{array}$ & $\begin{array}{l}\text { The reasons for the magnitude of the West African } \\
\text { epidemic are therefore likely to lie with non- } \\
\text { virological factors such as population density, } \\
\text { poverty, lack of access to medical care, funerary } \\
\text { practices, and failure to recognise the outbreak early }\end{array}$ & \multirow[t]{2}{*}{$\begin{array}{l}\text { Gatherer, D } \\
(2015)\end{array}$} \\
\hline $\begin{array}{l}\text { local investment in } \\
\text { health services } \\
\text { quality of medical } \\
\text { systems } \\
\text { amount of direct } \\
\text { foreign aid }\end{array}$ & $\begin{array}{l}\text { Limitation of future outbreaks depends on rapid } \\
\text { response, development of health infrastructure, and } \\
\text { infusion of human and material resources. } \\
\text { Physicians in endemic areas need to be aware of the } \\
\text { diffuse presentation of EVD in its early stages. }\end{array}$ & \\
\hline $\begin{array}{l}\text { mobility of general } \\
\text { public } \\
\text { gov't constraints on } \\
\text { mobility }\end{array}$ & $\begin{array}{l}\text { The populations of Guinea, Liberia, and Sierra } \\
\text { Leone are highly interconnected, with much cross- } \\
\text { border traffic at the epicenter and relatively easy } \\
\text { connections by road between rural towns and } \\
\text { villages and between densely populated national } \\
\text { capitals. }\end{array}$ & \multirow[t]{5}{*}{$\begin{array}{l}\text { WHO Ebola } \\
\text { Response Team } \\
(2014)\end{array}$} \\
\hline $\begin{array}{l}\text { no of identified } \\
\text { infected patients }\end{array}$ & $\begin{array}{l}\text { There are numerous reports of symptomatic persons } \\
\text { evading diagnosis and treatment, of laboratory } \\
\text { diagnoses that have not been included in national } \\
\text { databases, and of persons with suspected EVD who } \\
\text { were buried without a diagnosis having been made }\end{array}$ & \\
\hline $\begin{array}{l}\text { no of identified } \\
\text { infected patients } \\
\text { no of patients } \\
\text { quarantined } \\
\text { infectivity } \\
\text { mobility of infected } \\
\text { persons }\end{array}$ & $\begin{array}{l}\text { transmission can be stopped by a combination of } \\
\text { early diagnosis, contact tracing, patient isolation and } \\
\text { care, infection control, and safe burial }\end{array}$ & \\
\hline $\begin{array}{l}\text { extent of gov't } \\
\text { mobility control }\end{array}$ & $\begin{array}{l}\text { The critical determinant of epidemic size appears to } \\
\text { be the speed of implementation of rigorous control } \\
\text { measures. }\end{array}$ & \\
\hline $\begin{array}{l}\text { no of identified } \\
\text { infected patients } \\
\text { no of patients } \\
\text { quarantined }\end{array}$ & $\begin{array}{l}\text { To curtail transmission in the community, the period } \\
\text { from symptom onset to hospitalization (a mean of } 5 \\
\text { days but a maximum of }>40 \text { days) clearly needs to } \\
\text { be reduced }\end{array}$ & \\
\hline
\end{tabular}




\begin{tabular}{|c|c|c|}
\hline $\begin{array}{l}\text { degree of } \\
\text { concentration of } \\
\text { infected patients } \\
\text { mobility of general } \\
\text { public } \\
\text { infectivity } \\
\text { ability to diagnose } \\
\text { infected persons }\end{array}$ & $\begin{array}{l}\text { Forward projections suggest that unless control } \\
\text { measures - including improvements in contact } \\
\text { tracing, adequate case isolation, increased capacity } \\
\text { for clinical management, safe burials, greater } \\
\text { community engagement, and support from } \\
\text { international partners - improve quickly, these } \\
\text { three countries will soon be reporting thousands of } \\
\text { cases and deaths each week }\end{array}$ & \\
\hline $\begin{array}{l}\text { effectiveness of } \\
\text { curative treatments }\end{array}$ & $\begin{array}{l}\text { Experimental therapeutics and vaccines offer } \\
\text { promise for the future but are unlikely to be } \\
\text { available }\end{array}$ & \\
\hline quality of facilities & $\begin{array}{l}\text { The disintegration of the health care systems in the } \\
\text { affected countries is already having a profound } \\
\text { impact }\end{array}$ & $\begin{array}{l}\text { Farrar and Piot } \\
\text { (2014) }\end{array}$ \\
\hline $\begin{array}{l}\text { degree of border } \\
\text { control } \\
\text { degree of } \\
\text { concentration of } \\
\text { infected patients } \\
\text { mobility of general } \\
\text { public } \\
\text { infectivity } \\
\text { ability to diagnose } \\
\text { infected persons } \\
\text { funding for support } \\
\text { staff } \\
\text { funding for medical } \\
\text { staff } \\
\text { funding for drug } \\
\text { delivery } \\
\text { local investment in } \\
\text { health services } \\
\text { quality of medical } \\
\text { systems }\end{array}$ & $\begin{array}{l}\text { [T]here is now increased travel from previously } \\
\text { isolated areas, allowing for spread of the outbreak } \\
\text { into densely populated urban areas. Increased access } \\
\text { to medical care, with amplification of transmission } \\
\text { in health care facilities, has also likely contributed to } \\
\text { the larger outbreak. } \\
\text { Cultural and societal practices have contributed to } \\
\text { the extent of the outbreak in West Africa. Family } \\
\text { [put]themselves at high risk for infection through } \\
\text { contact with infectious materials: blood, feces, } \\
\text { vomit, or other body fluids. Family members are } \\
\text { fearful that it is the hospitals themselves that are } \\
\text { causing the infections; as a result, EVD cases and } \\
\text { their contacts have been hidden from health } \\
\text { authorities. ... limited availability of sanitation and } \\
\text { public health infrastructure. Burial practices } \\
\text {...include preparation of the body for burial and } \\
\text { close contact of family members with the } \\
\text { deceased.... }\end{array}$ & $\begin{array}{l}\text { Tosh PK, } \\
\text { Sampathkumar } \\
\text { P. (2014) }\end{array}$ \\
\hline $\begin{array}{l}\text { infectivity } \\
\text { mobility of infected } \\
\text { persons } \\
\text { gov't constraints on } \\
\text { mobility }\end{array}$ & $\begin{array}{l}\text { On October 22, the CDC announced that public } \\
\text { health authorities will begin active postarrival } \\
\text { monitoring of travelers whose travel originates in } \\
\text { Liberia, Sierra Leone, or Guinea. }\end{array}$ & \\
\hline $\begin{array}{l}\text { infectivity } \\
\text { mobility of infected }\end{array}$ & $\begin{array}{l}\text { Affected countries must also do a better job of } \\
\text { dealing with patients and educating the public about }\end{array}$ & $\begin{array}{l}\text { Check Hayden } \\
\text { E. (2014) }\end{array}$ \\
\hline
\end{tabular}




\begin{tabular}{|c|c|c|}
\hline persons & the disease, say doctors and scientists. & \\
\hline $\begin{array}{l}\text { infectivity } \\
\text { mobility of infected } \\
\text { persons }\end{array}$ & $\begin{array}{l}\text { Officials are likely to make more progress fighting } \\
\text { Ebola's spread if they explain their actions and show } \\
\text { concern for those affected }\end{array}$ & \\
\hline $\begin{array}{l}\text { gov't constraints on } \\
\text { mobility }\end{array}$ & $\begin{array}{l}\text { Travel restrictions may hamper the deployment of } \\
\text { personnel and support in the region, ultimately } \\
\text { creating a counter productive effect } \mathrm{i}\end{array}$ & \multirow[t]{2}{*}{$\begin{array}{l}\text { Gomes MFC, } \\
\text { Rossi L, et al. } \\
(2014)\end{array}$} \\
\hline $\begin{array}{l}\text { gov't constraints on } \\
\text { mobility } \\
\text { no of identified } \\
\text { infected patients }\end{array}$ & $\begin{array}{l}\text { The probability of any country to experience EVD } \\
\text { case importation depends on the passenger flow } \\
\text { from the areas affected by the outbreak, the case } \\
\text { numbers and the duration of the incubation time }\end{array}$ & \\
\hline $\begin{array}{l}\text { infectivity } \\
\text { mobility of infected } \\
\text { persons }\end{array}$ & $\begin{array}{l}\text { specific cultural elements and local beliefs must be } \\
\text { taken into account to ensure proper messages, } \\
\text { confidence, and close cooperation of the community }\end{array}$ & $\begin{array}{l}\text { Hewlett BS and } \\
\text { Amola RP } \\
\text { (2003) }\end{array}$ \\
\hline
\end{tabular}

Table 1: Extract from text analysis of descriptive Ebola papers showing concordance with ID variables 